\title{
Mauro Cappelletti and The Brazilian Procedural Law
}

\author{
Carlos Alberto Alvaro de Oliveira \\ Professor of Law at the \\ Federal University of Rio Grande do Sul \\ Member of the International Association of \\ Procedural Law
}

1. Brazilian judges have long enjoyed wide power in the appreciation of acts by the Executive and Legislative Branches. Although it lined up to the dual system in the early colonial days and even in imperial times, and adopted administrative litigation, the Brazilian Law promptly introduced itself into the unique system at the time of the first Republican Constitution, in 1891.

In the present day, a simple overview of the Federal Constitution of 1988 can evidence a wide jurisdictional control of the administration. Every act of a public character is subject to judicial review either by the State Courts or by the Federal Courts, case by case. Besides, in the wake of the Republican tradition, art. 5, subparagraph XXXV, clarifies that "the law will not exclude from judicial appreciation any damage or threat to rights." Furthermore: Brazilian citizens enjoy constitutional writs like those of the common law system: writ of mandamus ${ }^{1}$, habeas corpus ${ }^{2}$, and now

\footnotetext{
Federal Constitution, art $5^{\text {th }}$, subparagraph LXIX: "a writ of mandamus shall be granted to protect clear legal right, not supported by habeas corpus or habeas data, when the responsible for the ilegality or abuse of power is a public authority or an agent of a legal entity in the exercise of his/her duties for the Public Power." It is about a documental summary proceeding largely employed in the Brazilian juridical experience which is preferential to the other proceedings in trial, even allowing preliminary order if the pleading is relevant or fundamented and in case the measure is inefficient if the final sentence is granted.

2 Federal Constitution, art. 5, subparagraph LXVIII: "an habeas corpus shall be granted whenever someone suffers from or feels under the threat of violence or coercion in his/her liberty of locomotion, for ilegality or abuse of power."
} 
habeas data ${ }^{3}$, not to mention the writ of injunction ${ }^{4}$ an incomparable remedy in Comparative Law.

According to the doctrine and the constitutional system itself, there is no obstacle to the exam of excessive power by the Judicial Branch. It is also possible to perform a deconstitution of administration acts by the Judicial Branch, and there is also no limit to the possibility of judicial review of an act carried out by the administration, no matter what responsible authority it is.

In the substantial plan, the present Constitution has created as its fundamental principle the protection of meta-individual values like citizenship, people's dignity and the social value of work and free enterprise, proclaiming the desideratum of a free, fair, sympathetic society towards everybody's well-being, without any kind of discrimination (art $1^{\text {st }}$, subparagraphs II, III and IV, and $3^{\text {rd }}$, subparagraphs I and IV), at the same time limiting property use to its social function (art. $5^{\text {th }}$, subparagraph XXIII), values which naturally impose limits to extremely diverse kinds of abuse. Several hypotheses integrate the category of collective rights in the new constitutional order, like the right to a balanced environment (art. 225, caput), admiting redress to it (art. $225, \S 3^{\text {rd }}$ ); respect to the full development of a city's social function including the guarantee of its inhabitants' well-being (art. 182); objective civil liability for nuclear damage (art. 21, paragraph XXIII, $c$ ) and the preservation of the urban environment historical and cultural continuity and unity (art. 18, $4^{\text {th }}$ ). It is also important to mention that art. 170, V, has elevated "consumed defense" into the outstanding condition of the principle of the economic order, empowering the Union, the States and the Federal District to legislate in a concurrent way about consumer damage liability (art. 24, subparagraph VIII).

3 Federal Constitution, art. 5, subparagraph LXXII: "an habeas data shall be granted: a) to ensure information about the petitioner recorded in public or governmental register or database; $b$ ) for data ammendment, when you do not prefer to do it by confidential, judicial or administrative proceedings." ${ }^{4}$ Federal Constitution, art. 5, subparagraph LXXI: "a writ of injunction will always be granted every time lack of a regulating norm makes the exercise of constitutional rights and liberty and the prerogatives inherent to nationality, sovereignty and citizenship unfeasible". The Supreme Court of Brazil has been extremely cautious in the application of this norm. It as much as notifies the authority in order to supply the necessary regulation, tackling the matter as unconstitutionality for omission, regulated from art. $103, \S 2$ of the Constitution, because it does not regard the writ of injunction as a constitutional successor of the political-juridical functions of the state defaulters - the constitutional principle of functional division of powers must be observed. Nevertheless, in rare cases, recognizing the National Congress unconstitutional default and previous legal notice of the institution, the writ petitioners may be assured the possibility of lawsuits according to their interests, provided the lack of norm is supplied (thus, v.g., in the trial of Writ of Injunction 248-DF, Justice Celso de Mello as a relator, 11/22/1991, RTJ,139/702). 
Within these rules, the infraconstitutional legislation has long been enpowering Brazilian judges to the practice of empire-like acts by means of warrants and writs to the public authorities and to individuals, establishing res judicata erga omnes or ultra parte of court decisions in claims of social or political nature ${ }^{5}$, or creating autonomous summary guardianships ${ }^{6}$.

2. The outline of public and social guidelines which have been informing the Brazilian social procedure for a long time proves to be important because it allows an appraisal of the actual dimension of Mauro Cappelletti's work in Brazil, whose doctrinal organization displays as a consistent point a phenomenological aproach both inspired by a critical view of the concrete situation and centered around a solution project, and thus a reform one, with a reflection on a practical basis.

For nearly thirty five years, Mauro Cappelletti has been essentially concerned about fundamental issues like the orality principle, the fundamental guarantees of the proceedings and their social dimension, access to justice either by means of participation or by the protection of the so-called diffuse interests, alternative ways of guardianship and coexistential justice based on conciliation ways, the judge's role and his responsibility, not to mention, of course, the question of ideology?

5 Inasmuch as to quote the most important federal statutes, the following may be referred; a) $n$. 1.533 from December 31, 1951, about the writ of security, b) n. 4.717 from June 29, 1965, about the popular action; c) n. 7.437 from July 24,1985 , regulating the public civil action; d) n. 8.078 from 9/11/ 1990, which establishes the so-called Consumer Defense Code. In the constitutional sphere, art. 5, subparagraph LXXIII from the Federal Constitution has spread the range of popular action, which has also begun to protect - apart from rights of strictly public nature - diffuse rights, like the environment and the historical and cultural patrimony. Furthermore, Art. 129, subparagraph III, attributes constitutional status to the popular civil action, a fundamental means to rights protection and diffuse and collective interests.

6 Thus, for example, Law n. 5.478 from July 25,1968 , which regulates alimony action within the sphere of Family Law.

${ }_{7}$ It is what results from the reading of a conference delivered by him in the $1^{\text {st }}$ Brazilian Conference of Civil Procedural Law, held in Curitiba, Brazil, in May 1994, where he tries to do what he called "a hard conscience search" about his professional activity. See Problemas de Reforma do Processo Civil nas Sociedades Contemporâneas, in O Processo Civil Contemporâneo, coordinator Luiz Guilherme Marinoni, Curitiba, Juruá Editora, 1994, p. 9-30. 
He states that orality is an important instrument not only to solve the problem of extreme delay in proceedings but also to improve the quality of the Civil Courts, especially concerning realization of evidence and judges' breast of the court, therefrom the importance of the party's testimony by himself. The splendid cathedra thesis La Testimonianza della Parte nel Sistema dell 'Oralità (Contributo alla Teoria della Utilizzazione Probatória del Sapere delle Partinel Processo Civile), Milano, Giuffrè, 1962, is from that time, followed by Procédure Orale et Procédure Écrite, Milano-New York, Giuffrè-Oceana, $1971^{8}$.

In the field of fundamental guarantees of the proceedings, he highlights the importance of the need for judicial freedom before the political power, but not without pointing out that impartiality and passiveness cannot be confounded. Thus the distinction between "party- presentation principle or principle of dispositive election in a substantial or proper sense" and "party- presentation principle or principle of dispositive election in a procedural or improper sense" and the importance given to the guarantee of the due process of law, adding social guarantees to the formal constitutional guarantees, and second generation to first generation human rights, which are intended to assure and provide rights to everyone instead of working as a fake to the favoured party. Along this line, the general report of the Conference of the International Association of Legal Science, from 1971: Fundamental Guarantees of the Parties in Civil Proceedings ${ }^{10}$ and innumerable other papers ${ }^{11}$.

\footnotetext{
${ }^{8}$ General report presented at the VIII International Conference of Comparative Law organised by the International Academy of Comparative Law in Pescara, from August 25 to September 5, 1970. Among others on this theme, also see: Interrogatorio della parte e principii fondamentali del processo civile nell'Europa comunista, Rivista di Diritto Processuale, XIV(1959):39-59; Efficacia di prove illegittimamente ammesse e comportamento della parte, Rivista di Diritto Civile, VII-I(1961):556-575, Giuramento, in Enciclopedia Forense, vol. III, Milano, Vallardi, 1958, II giuramento della parte nel processo litisconsortile, Rivista Trimestrale di Diritto e Procedura Civile, IX-4(1955):1151-1195, Valore attuale del principio di oralità, a report presented at the II Latin American Conference of Procedural Law (Mexico City, February 1960), Giur. It., CXII-IV(1960):89-95. Still in the volume Giustizia e società, Milano, edizioni di Comunità, 1977: L'oralità nel processo civile italiano: ideale contro realtà, p. 130144.

${ }^{9}$ Iniziative Probatorie del Giudice e Basi Pregiuridiche della Struttura del Processo, Rivista di Diritto Processuale, XXII(1967):407-428.

${ }^{10}$ In Fundamental Guarantees of the Parties in Civil Litigation, published by Mauro Cappelletti and Denis Tallon, Milano-New York, Giuffrè-Oceana, 1973, p. 661-773.

${ }^{11}$ Beginning with La prejudizialità costituzionale nel processo civile, Milano, Giuffrè, 1957, following: II controllo giudiziario di costituzionalità delle leggi nel diritto comparato, settima ristampa, Milano, Giuffrè, 1978, Diritto di azione e di difesa e funzione concretizzatrice della giurisprudenza costituzionale (art. 24 Costituzione e "due process of law clause"), Giur. Cost., VI(1961):1284-1292, II significato del controllo giudiziario di costituzionalità delle legge nel mondo contemporâneo, Rivista di Diritto Processuale, XXIII(1968):483-500, II ricorso costituzionale nel sistema delle impugnazioni, Rivista Trimestrale di Diritto e Procedura Civile, XXII(1968):1056-1061.
} 
Another important domain of Mauro Cappelletti's investigations is related to social dimension awareness of the proceedings, which he named copernic revolution, because it breaks the traditional aproach, leaving room for the procedural experts to turn their attention from Law as a rule to Law in its effective role in the concrete world, and thus focus the procedure in the light of the users necessities ${ }^{12}$. It may be said that the issue has been object of his attention for a long time because the famous essay about Procedural Law ideology ${ }^{13}$ dates back from 1962.

The problem of access to justice is also a relevant matter there, with its questioning about highly expensive proceedings fees and delay in judgment delivery, judges' powers, and the protection of the so-called diffuse interests, typical of a mass society ${ }^{14}$.

This scenario also tackles the question of the use of differentiated procedural techniques to make justice more accessible to everyone: procedures simplification and the creation of alternative ways either by the incentive of conciliation (coexistential Justice) ${ }^{15}$ or by the establishment of small claims courts.

Yet another frequently emphasized aspect of Mauro Cappelletti's work involves, as it could only be, the judge's role in the proceedings. He highlights the judge's essentially creative activity, pointing out the growing intensity of judges' discretionary powers in the modern civil procedure and the politicization in the exercise of their functions, wich draws our attention to their legal and social responsibility ${ }^{16}$.

12 Cappelletti, O processo civil contemporâneo, cit., p. 15. About it, the essays Libertà individuale e giustizia sociale nel processo civile italiano and Aspetti sociali e politici della procedura civile (Riforme e tendenze evolutive nellËurpa occidentale e orientale), in Giustizia e Società, cit., p. 23-47 e 48-105. 13 Cappelletti, Ideologie nel diritto processuale, Rivista Trimestrale di Diritto e Procedura Civile, XVI(1962):193-291.

14 This way, the extraordinary The Florence Access-to-Justice Project, from which Access to Justice, A World Survey derived, published by Mauro Cappelletti and Bryant Garth, Milano, Giuffrè, 1978, in which is the publishers' general report, Access to Justice: The Worldwide Movement to Make Rights Effective. A General Report, vol. I, book I, p. 5-124, with its three "waves": legal aid to the poor, the representation of diffuse interests, and a wider and more updated conception of access to Justice. With the same drive, the general report of the $9^{\text {th }}$ Conference of the International Academy of Comparative Law, Teeran, from September 27 to October 4, 1974, The Role of the Ministerre Public, the Prokuratura, and the Attorney General in Civil Litigation - With a Glance at Other Forms of Representation of Public and Group Interests in Civil Proceedings, in Mauro Cappelletti and J. A. Jolowicz, Public Interest Parties and the Active Role of the Judge in Civil Litigation, prefaced by C. J. Hamson, Milano-New York, Giuffrè-Oceana, 1975, p. 13-153. Also see: II processo como fenomeno sociale di massa, II Ponte, XXV(1969):1234-1240, La giustizia è uguale per tutti?, Resistenza, XXIII6(giugno 1969):8, Povertà e giustizia, Foro Italiano, 91-V(1968):114-119.

15 As Cappelletti warns, $O$ processo civil contemporâneo, cit., p. 21 , deals with a kind of Justice which takes into consideration the whole situation where the litigation episode is involved and which is intended to heal and not to exasperate the situation under tension: The "Kampf ums Recht must give in to the Kampf um die Billigkeit, that is, to the struggle for equity, for a fair, acceptable solution to all the parties."

16 The fruit of this line of research may be quoted as: The Mighty Problem of Judicial Review, $53 \mathrm{~S}$. Calif. L. Rev. 409(1980), The Law-Making Power of the Judges and its Limits, 8 Monash Univ. L. Rev. 15(1981), Giudici Legislatori?, Milano, Giuffrè, 1984, Giudici Irresponsabili? (Studio comparativo sulla responsabilità dei giudici), Milano, Giuffré, 1988. 
3. In Brazil, his work was widely spread and is still being studied and quoted, not to mention the remarkable influence of his presence in several conferences and workshops where he delivered lectures and speeches.

As early as in 1969, the Rio Grande do Sul Appelate Court Report published a translation by Athos Gusmão Carneiro of the seminal essay Ideologie nel diritto processuale ${ }^{17}$. Later, the publisher Sérgio Antonio Fabris, who has been contributing so much to the spread of foreign classics among us, would publish the Brazilian translation of Il controllo giudiziario di costituzionalità delle leggi nel diritto comparato, Access to Justice: The Worldwide Movement to Make Rights Effective. A General Report; Giudici Irresponsabili? and Giudici Legislatori? ${ }^{18}$.

It would not be hard to portray his presence in the work of the top procedural experts in Brazil for his frequently quoted and commented fundamental ideas. I abstain to end up the inventory for fear of some omission, always unpleasant, mainly because his doctrine is so widely spread and accepted and the new way of seeing Procedural Law that his writings inspire is so greatly welcomed.

Above all, it is very easy to see the influence of Mauro Cappelletti's doctrine in three very important legislative statutes for citizens' rights defense which concern issues as important as the diffuse interests, the smal claims courts and consumer rights, which were all so important to him, as it was mentioned before.

Cappelletti's ideas were strong and decisive enough for the implementation of small claims special courts (Federal Statute n. 7.244, from 11/7/1984), which were later renamed as special courts (Federal Statute n. 9.099, from 9/26/1995), as the whole system is based on an easier access to justice, proceedings deformalization, increment of orality and equal protection, with the effectiveness deriving from it. The community's participation through lay judges and conciliators could be added.

Concerning the issue, Professor Cândido Rangel Dinamarco, one of the authors of the bill eventually turned into Federal Statute n. 7.244/84, suggests a greater access way to the Judicial Branch as the democratic aspiration of the society and reports that "This concern has been coming up in the work of top jurists, especially the monumental work coordinated by Mauro Cappelletti about access to justice, with the contribution of specialists from all over the world" ${ }^{19}$.

17 A Ideologia no Processo Civil, in Revista de Jurisprudência do Tribunal de Justiça do Rio Grande do Sul, 13(1969):2-17.

18 Following: O controle Judicial de Constitucionalidade das Leis no Direito Comparado, Porto Alegre, 1984, translated by Aroldo Plínio Gonçalves and revised by José Carlos Barbosa Moreira, Acesso à Justiça, Porto Alegre, 1988, translated and revised by Ellen Gracie Northfleet, Juizes Irresponsáveis, Porto Alegre, 1989, translated and revised by Carlos Alberto Alvaro de Oliveira, and Juizes Legisladores?, Porto Alegre, 1993, translated and revised by Carlos Alberto Alvaro de Oliveira. The latter is dedicated to José Carlos Barbosa Moreira and Sérgio Bermudes, having been suggested that thanks to these friends, he was fortunate enough to feel "at home in this big and wonderful country: Brazil."

19 Cândido Rangel Dinamarco, Principios e Critérios no Processo das Pequenas Causas, in Juizado Especial de Pequenas Causas, a collection of essays coordinated by Kazuo Watanabe, São Paulo, $\mathrm{RT}, 1985$, p. 110 . As a matter of fact, most papers in the book refer to the outstanding contribution of Mauro Cappelletti. 
Another important legal statute of the Brazilian Law is established in Federal Statute n. 7.347, from 7/24/1985, which governs the public civil action of liability for damage to the environment, consumer, goods and rights of artistic, aesthetic, touristic and landscaping value, as well as to any other diffuse or collective interest.

In this matter, the pioneer work of Professor José Carlos Barbosa Moreira is duely recognized. It was prepared in Florence and published in Brazil in 1977, under the title A ação popular do Direito Brasileiro como instrumento de tutela jurisdicional dos chamados interesses difusos ${ }^{20}$, because it was after this essay that the Brazilian doctrine began to worry about the issue. It contained several references to the ideas and the work of Mauro Cappelletti, whose influence is confirmed by Professor Ada Pellegrini Grinover $^{21}$, along with Professors Cândido Rangel Dinamarco, Kazuo Watanabe and Waldemar Mariz de Oliveira Jr, authors of the Bill.

Not coincidently, three bright procedural experts who, along with other jurists, wrote the bill turned into the Brazilian Consumer Act, (Federal Statute n. 8.078, from September 11, 1990), Professors Ada Pellegrini Grinover, Kazuo Watanabe and Nelson Nery Júnior, are very linked to Mauro Cappelletti's work, making his influence clear in so many regulations of such an important legislative monument In their comments on the Act, they pay him recognized homage, mainly about the class actions statuted there ${ }^{22}$. Professor Ada Pellegrini Grinover claims, with a clear mention to Cappelletti's work, that exactly because it is related to consumer protection, legislators' concern right now is towards this protection's effectiveness and with an easier access to justice ${ }^{23}$. So does Professor Kazuo Watanabe by highlighting, also quoting Cappelletti, the manifest intention of the Brazilian Congress to increment the substantial instrumentality and the greater effectiveness of the proceedings and adapting it to the new socio-economic reality we are living, marked so strongly by mass economy ${ }^{24}$.

\footnotetext{
20 Dedicated to Liebman, the essay was originally published in Temas de Direito Processual, São Paulo, Saraiva, 1977, p. 110-123, and later in Studi in onore di Enrico Tullio Liebman, vol. IV, Milano, Giuffrè, 1979, p. 2673-2692.

21 Novas tendências na Tutela Jurisdicional dos Interesses Difusos, in O Processo em sua Unidade - II, Rio de Janeiro, Forense, 1984, p. 88-121. As informed there, p. 116, the bill was initially presented at the I National Conference of Procedural Law, held in Porto Alegre from July 11 - 16, 1983, where José Carlos Barbosa Moreira reported, in a favourable opinion, that he made profound, important considerations about the theme, suggesting a control prevision of the liminar measure in the inhibiting civil actions, apart from formal modifications. After the favourable manifestations by Professors Galeno Lacerda, Calmon de Passos and Ovidio Baptista da Silva, it was passed by acclamation.

${ }_{22}$ See Ada Pellegrini Grinover et allia, Código Brasileiro de Defesa do Consumidor Comentado pelos Autores do Anteprojeto, 6 ${ }^{\mathrm{a}}$. ed., Rio de Janeiro, Forense Universitária, 1999, passim.

${ }_{23}$ Ada Pellegrini Grinover, Código Comentado, cit., p. 701.

24 Kazuo Watanabe, Código Comentado, cit., p. 706.
} 
4. Any modern thinking about the proceedings must take their internal and external connections into consideration. The sheer study of technique - a simple means to obtain a certain result - is not enough, because the proceedings, as a cultural phenomenon, conform to a society's values, ideas, utopies, power strategies, social, economic and political factors. So, it is always necessary to pay attention to the ties of the outside social reality: the greatest myopia a procedural expert may suffer from is to regard the proceedings as a measurement for everything. No attempt to control state discretion and at the same time establish patterns which allow the proceedings to reach their goals in razonable time and also add up to justice may result fruitful if it does not regard political, cultural and axiological currents of the conditioning and determining factors of its structural process and organization ${ }^{25}$.

Mauro Cappelletti was the greatest inspirer of our times towards a more humanistic and realistic approach to feeling and thinking the procedural phenomenon. His sociological view of the proceedings, inherited from Piero Calamandrei, the shared experience of the civil law and the common law and the skill of his refined spirit to post-modernity odds make him a priviledged observer of the great conflicts of value of the $20^{\text {th }}$ Century, and most of all, an insuperable reformer in the studies of Procedural Law. 